\title{
Merdeka Belajar dan Kampus Merdeka Dalam Pandangan Filsafat Pendidikan Humanisme
}

\author{
Nora Susilawati \\ Universitas Negeri Padang \\ Email: norasusilawati1973@gmail.com
}

\begin{abstract}
Abstrak
Merdeka Belajar-Kampus Merdeka adalah kebijakan Menteri Pendidikan dan Kebudayaan yang bertujuan mendorong mahasiswa agar menguasai berbagai keilmuan untuk memasuki dunia kerja. Kebijakan Merdeka Belajar-Kampus Merdeka sesuai dengan Permendikbud Nomor 3 Tahun 2020 tentang Standar Nasional Pendidikan Tinggi. Dalam pandangan humanisme, merdeka belajar memberikan kesempatan kepada mahasiswa untuk belajar secara otonomi atau mandiri serta bertanggung jawab terhadap dirinya sendiri. Mahasiswa berhak mengikuti pembelajaran di luar prodi dalam kampus dan luar kampus dalam berbagai kegiatan seperti pertukaran pelajar, magang/praktik kerja, asistensi mengajar di satuan pendidikan, penelitian, proyek kemanusiaan, kegiatan wirausaha, studi/proyek independen, dan membangun desa/Kuliah Kerja Nyata Tematik (KKNT). Terlibatnya mahasiswa dalam kegiatan-kegiatan tersebut dapat memberikan pengalaman belajar (experience learning) sebagai bekal menghadapi hidup dan kehidupan di masa depan. Untuk mewujudkan pengalaman belajar tersebut perguruan tinggi harus membangun kerjasama dengan dunia usaha/industri dan pemerintah. Kerjasama didasari dalam kerangka meningkatkan profesionalitas civitas akademika. Kerangka ini akan mempengaruhi perumusan kurikulum dalam penentuan capaian pembelajaran (learning outcomes) dan penempatan kuliah di luar perguruan tinggi. Kualitas belajar dan kebermaknaan belajar dapat dicapai dengan menerapkan prinsip belajar humanistik yaitu belajar bagaimana belajar (learning how to learn), pembelajaran mandiri, memotivasi diri, dan pendidikan afektif. Dengan demikian, tujuan pendidikan MBKM yang diharapkan untuk mengembangkan hard skills dan soft skills, menyiapkan mahasiswa lebih siap dan relevan dengan kebutuhan perkembangan zaman, menyiapkan lulusan sebagai pemimpin masa depan bangsa yang unggul dan berkepribadian dapat dicapai secara optimal.
\end{abstract}

Kata Kunci: Filsafat Pendidikan, Humanisme, Merdeka Belajar-Kampus Merdeka

\section{Abstract}

Learning Independent-Independent Campus is a policy of the Minister of Education and Culture which aims to encourage students to master various discipline to enter the world of work. The policy of Freedom Learning-Independent Campus is in accordance with the regulation of the Minister of Education and Culture Number 3 of 2020 concerning National Standards for Higher Education. In the view of humanism, independent learning provides oppotunities for students to learn autonomously or independently and be reaponsible for themselves. Students are entitled to take part in learning ouside the on-campus and off-campus study programs in various activities such as students exchange, internships/workpractices, teaching assistance in educational units, research, humanitarian projects, entrepreneurial activities, independent studies/projects, and building villages/work colleges are thematic. The involment of students in these activities can provide learning experiences as a provision to face life and life in the future. To realize this learning experience, higher education institutions must build cooperation with the bussiness world and the goverment. Cooperation is based in the framework of improving the professionalism of the academic community. This framework will influence the formulation of the curriculum in determining learning outcomes and placement of course aoutside tertiary institutions. Learning quality and meaningful learning can be achieved by applying the principles of humanistic learning, namely learning how to learn, independent learning, motivation and affective education. Thus, the goal of MBKM education which is expected to develop hard skills and soft skills, prepare students to be more ready and relevant to the need of the tmes, prepare graduates as futureleaders of the nation who are superior and have personality can be achieved optimally.

Keywords: Educational Philosophy, Humanism, Learning Independent-Independent Campus

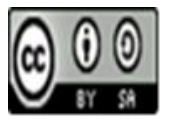

Jurnal Sikola: Jurnal Kajian Pendidikan dan Pembelajaran Vol. 2, No. 3, Th. 2021 
JURNAL

VOL. 2 NO. 3 MARET 2021

http://sikola.ppj.unp.ac.id

Email: sikola@ppj.unp.ac.id

ISSN: 2686-3413 (Print) 2715-1735 (Online)

DOI: https://doi.org/10.24036/sikola.v2i3.108

Received: January 2, 2021

Revised: March 30, 2021

Accepted: March 31, 2021 


\section{Pendahuluan}

Filsafat merupakan hal yang penting bagi pendidikan, karena tanpa filsafat pendidik akan bisa kehilangan pedoman ketika merancang, melaksanakan, dan meningkatkan kualitas pendidikan (Ornstein, 2007). Zais (1976) juga menjelaskan bahwa filsafat mengkaji knowledge of the good life yaitu membantu pendidik memahami hakikat hidup yang baik bagi individu dan masyarakat. Kehidupan yang baik inilah yang menjadi dasar dan domain pendidikan dan kurikulum. Filsafat dapat membantu pengembang kurikulum dalam mentukan kriteria tujuan, proses, dan sasaran kurikulum Pendidikan (Zais, 1976). Hal inilah yang mendasari alasan mengapa filsafat merupakan salah satu fondasi kurikulum, karena filsafat memuat pengetahuan yang baik bagi siswa atau mahasiswa untuk mencapai keberhasilan hidup.

Terkait dengan filsafat pendidikan, Ornstein dan Hunkins (2013) mengemukakan bahwa filsafat pendidikan menentukan keputusan, alternatif dan pilihan kependidikan yang dipedomani pendidikan dan pengembang kurikulum (Ornstein \& Hunkins, 2013). Filsafat pendidikan adalah aktivitas berpikir yang mengatur, menyelaraskan dan memadukan proses pendidikan. Pohan (2019) menyatakan bahwa filsafat pendidikan dijadikan dasar dan pandangan dasar bagi pelaksanaan Pendidikan (Pohan, 2019).

Konsep pendidikan dapat ditinjau dari dua aspek yaitu membantu dan menolong. Hakikat pendidikan membantu yaitu membantu seseorang menjadi manusia seutuhnya, karena manusia tidak bisa hidup secara individual namun ia membutuhkan bantuan dari orang lain. Salah satu bentuk membutuhkan bantuan itu adalah pendidikan. Berikutnya, hakikat pendidikan adalah menolong manusia menjadi manusia. Pada setiap manusia memiliki potensi ada yang menjadi manusia ada yang tidak menjadi manusia (memiliki sifat kebinatanga). Di sinilah pentingnya peranan pendidikan untuk memanusiakan manusia. Oleh sebab itu, dengan pendidikan manusia diarahkan ke perbuatan yang benar dan mengembangkan potensi manusia agar memiliki kompetensi dalam hidupnya.

Pendidikan dapat dikatakan sebagai aplikasi pemikiran filosofis. Oleh sebab itu filsafatlah yang memberikan kerangka konseptual yang holistik tentang manusia dan pendidikan. Pemaknaan pendidikanpun berawal dari pemaknaan hakikat manusia. Berbagai aliran filsafat yang berbicara tentang manusia melahirkan teori pendidikan yang dipraktikan dalam proses pembelajaran yang dirancang oleh pendidik atau pakar pendidikan. Filsafat dikatakan sebagai induk dari segala pemikiran dalam teori pendidikan

Munculnya kebijakan Menteri Pendidikan dan Kebudayaan pada tahun2020 ini dengan adanya Merdeka Belajar dan Kampus Merdeka (MBKM) memberikan pergeseran pandangan di dunia pendidikan termasuk pendidikan di perguruan tinggi. Konsep Merdeka Belajar dan Kampus Merdeka terkandung arti kemandirian dan kemerdekaan bagi lembaga pendidikan baik di sekolah maupun perguruan tinggi. Menurut Nadiem Makarim, konsep merdeka belajar dipilih karena terinspirasi dengan filsafat K.H Dewantara dengan esensi pendidikannya bermakna kemerdekaan dan kemandirian. Merdeka belajar dianggap relevan dan tepat dilaksanakan di era demokrasi pendidikan saat ini. Makna merdeka ini dapat diberlakukan bagi pendidik di kelas untuk bebas memilih metode mengajar yang tepat untuk anak didiknya dan merdeka memilih elemen-elemen yang terbaik dalam kurikulum. Makna kemerdekaan dan kebebasan merupakan pendidikan yang menekankan pada demokrasi pendidikan.

Merdeka Belajar dan Kampus Merdeka merupakan suatu bentuk reformasi yang dilakukan dalam pembelajaran mulai dari jenjang pendidikan prasekolah hingga pendidikan tinggi. Reformasi dalam pembelajaran merdeka belajar ini didasarkan pada Peraturan Menteri Pendidikan dan Kebudayaan Republik Indonesia Nomor 3 Tahun 2020 Pasal 15 tentang Standar Nasional Pendidikan Tinggi.

Dengan adanya kebijakan pemerintah di atas, maka perguruan tinggi di Indonesia melakukan perubahan kurikulum. Dalam Kurikulum Merdeka Belajar dan Kampus Merdeka, mahasiswa diberikan kesempatan untuk mengikuti perkuliahan di luar program studi dalam 
perguruan tinggi yang sama selama satu semester atau setara dengan 20 sks. Untuk hal ini, perkuliahan terbatas pada mata kuliah wajib yang telah ditetapkan di universitas. Selanjutnya, mahasiswa juga diberi kesempatan maksimal dua semester untuk mengikuti perkuliahan di luar perguruan tinggi, namun masih dalam program studi yang sama. Misalnya, Mahasiswa Program Studi Pendidikan Sosiologi Fakultas Ilmu Sosial Universitas Negeri Padang (UNP) dapat mengikuti perkuliahan di Universitas Negeri Jakarta (UNJ). Dalam pelaksanaannya, kedua program studi melakukan kerjasama antar universitas. Selain mengikuti perkuliahan di luar perguruan tinggi, mahasiswa juga dapat mengikuti kegiatan magang, proyek desa, mengajar di sekolah-sekolah, penelitian, pertukaran mahasiswa atau membangun start up.

Dari pemaparan di atas, terlihat bahwa pada program Merdeka Belajar dan Kampus Merdeka ini terdapaat suatu inovasi belajar sehingga dapat menghasilkaan mahasiswa yang inovatif, kreatif dan sekaligus dapat mengembangkan potensi dirinya dalam bidang yang dipilih. Pelaksanaan di lapangan, mahasiswa dapat berperan sebagai pendipta kerja (job creator).

Beberapa artikel yang telah ditelusuri terkait dengan konsep merdeka belajar dalam pandangan filsafat pendidikan yaitu tulisan dari Dela Khoirul Ainia (2020) menjelaskan bahwa merdeka belajar memiliki relevansi dengan pemikiran filsafat Ki Hajar Dewantara tentang pendidikan yang mempertimbangkan aspek keseimbangan cipta, rasa, dan karsa serta siswa diharapkan mengimplementasikan nilai-nilai karakter bangsa Indonesia dalam kehidupan seharihari. Berikutnya, Siti Mustaghfiroh (2020) menjelaskan konsep merdeka belajar memiliki arah dan tujuan yang sama dengan konsep aliran filsafat pendidikan progresivisme John Dewey (Mustaghfiroh, 2020). Keduanya sama-sama memiliki konsep kemerdekaan dan keleluasaan kepada lembaga pendidikan untuk mengeksplorasi potensi peserta didik secara maksimal sesuai dengan minat dan bakatnya. Selanjutnya, juga dijelaskan bahwa merdeka belajar menjadi salah satu solusi kongkrit untuk mengatasi permasalahan pendidikan yang begitu komplit. Berbeda dengan tulisan ini, akan menjelaskan Merdeka Belajar dan Kampus Merdeka dalam pandangan filsafat pendidikan humanisme. Digunakannya filsafat pendidikan humanisme ini karena dalam Merdeka Belajar dan Kampus Merdeka memberikan peluang atau kesempatan kepada mahasiswa untuk dapat mengembangkan potensi dirinya secara kreatif dan inovatif dalam perkuliahan di dalam perguruan tinggi, luar perguruan tinggi, dunia industri, dan masyarakat.

Dengan mengkaji merdeka belajar dan kampus merdeka dari sudut pandang filsafat pendidikan yang berbeda akan memberikan keberagaman pandangan dalam literatur, khususnya dalam kajian filsafat pendidikan. Keberagaman pandangan akan dapat mengungkap sisi merdeka belajar secara lebih dalam dan komprehensif. Untuk itu, fokus masalah dalam tulisan ini adalah mengkaji Merdeka Belajar dan Kampus Merdeka (MBKM) dalam pandangan filsafat pendidikan humanisme.

\section{Metode Penelitian}

Untuk memperoleh informasi terkait dengaan Merdeka Belajar dan Kampus Merdeka serta filsafat pendidikan humanisme diperlukan beberapa literatur, buku-buku, artikel dan referensi lain yang berhubungan dengan kebutuhan penulisan artikel ini. Dengan demikian, metode penelitian yang digunakan adalah studi kepustkaan. Menurut M. Nazir (1988), metode studi kepustakaan merupakan teknik pengumpulan data yang menggunakan kajian penelaahan terhadap buku-buku, literatur-literatur, catatan-catatan dan laporan-laporan yang berhubungan dengan masalah yang dipecahkan (Nazir, 1988). Informasi yang didapatkan dari berbagai buku, jurnal dan literatur lainnya bisa menjelaskan Merdeka Belajar dan Kampus Merdeka dalam pandangan filsafat pendidikan humanisme. Selanjutnya, studi kepustakaan dapat mempertajam konsep, teoritis, dan informasi tentang karya ilmiah dan penelitian yang sejenis dengan yang penulis lakukan (Danim, 2002). Berbagai informasi yang telah diperoleh dari berbagai literatur dapat dijadikan kajian Merdeka Belajar dan Kampus Merdeka dalam pandangan filsafat pendidikan sebagai sumber 
kekinian, memberi pandangan yang berbeda, dan pemutakhiran dari berbagai bahan sejenis yang telah ditulis oleh beberapa penulis sebelumnya.

\section{Hasil dan Pembahasan}

\section{Merdeka Belajar dan Kampus Merdeka}

Merdeka Belajar dan Kampus Merdeka merupakan salah satu kebijakan Menteri Pendidikan dan Kebudayaan Nadiem Makarim. Ada dua konsep yang esensial dalam "Merdeka Belajar" dan "Kampus Merdeka". Pertama, konsep merdeka belajar mengandung arti adanya kemerdekaan berpikir. Menurut Nadiem Makarim bahwa esensi kemerdekaan berpikir harus dimulai terlebih dulu oleh para pendidik. Pandangan seperti ini harus dilihat sebagai suatu upaya untuk menghormati perubahan dalam pembelajaran di lembaga Pendidikan baik di sekolah dasar, menengah maupun perguruan tinggi.

Kedua, kampus merdeka merupakan kelanjutan dari konsep merdeka belajar. Kampus merdeka merupakan upaya untuk melepaskan belenggu untuk bisa bergerak lebih mudah. Arti kampus merdeka adalah:

a. Adanya otonomi perguruan tinggi baik perguruan tinggi negeri maupun swasta. Perguruan tinggi memiliki otonomi untuk melakukan pembukaan atau mendirikan program studi baru. Otonomi akan diberikan bagi perguruan tinggi yang memiliki akreditasi A dan B. Selanjutnya, perguruan tinggi tersebut telah melakukan Kerjasama dengan organisasi atau univeritas yang termasuk dalam QS Top 100 World Universities. Kerjasama berbentuk penyusunan kurikulum, praktik kerja atau magang serta penempatan kerja bagi mahasiswa.

b. Program re-akreditasi otomatis. Program ini bersifat otomatis bagi semua peringkat dan bersufat sukarela bila perguruan tinggi atau prodi telah siap untuk naik peringkat. Akreditasi yang telah ditetapkan oleh BAN-PT tetap berlaku selama lima tahun dan akan diperbaharui secara otomatis. Pengajuan Kembali dilakukan paling cepat 2 tahun setelah mendapatkan akreditasi terakhir. Bagi perguruan tinggi atau prodi yang telah memperoleh akreditasi A, maka diberikan kesempatan untuk memperoleh akreditasi Internasional.

c. Kebebasan bagi perguruan tinggi negeri BLU (Badan Layanan Umum) dan Satker (Satuan Kerja) untuk menjadi PTN BH (Perguruan Tinggi Negeri Badan Hukum).

d. Hak belajar selama tiga semester di luar program studi. Perguruan tinggi wajib memberikan hak untuk mahasiswa secara sukarela mengambil atau tidak di luar perguruan tingginya sebanyak dua semester atau setara dengan 40 SKS. Selanjutnya, mahasiswa juga dapat mengambil sks di prodi lain di dalam kampus sebanyak satu semester.

Hak belajar tiga semester di luar program studi adalah menyiapkan kompetensi mahasiswa menghadapi perubahan sosial, budaya, dunia industri dan kemajuan teknologi yang begitu pesat. Kompetensi mahasiswa harus disesuaikan dengan tuntutan zaman yang mengalami perubahan tersebut sehingga adanya link and match dengan dunia industri dan dunia kerja serta masa depan. Dalam Peraturan Menteri Pendidikan dan Kebudayaan Republik Indonesia Nomor 3 Tahun 2020 Pasal 15 tentang Standar Nasional Pendidikan Tinggi menyatakan bahwa:

1. Bentuk pembelajaran dilakukan dalam program studi dan di luar program studi.

2. Bentuk pembelajaran di luar program studi merupakan proses pembelajaran yang terdir dari:

a) Pembelajaran dalam program studi lain pada perguruan tinggi yang sama;

b) Pembelajaran dalam program studi yang sama pada perguruan tinggi yang berbeda;

c) Pembelajaran dalam program studi lain pada perguruan tinggi yang berbeda;

d) Pembelajaran pada lembaga non perguruan tinggi. 
3. Proses pembelajaran di luar program studi dilaksanakan berdasarkan perjanjian kerjasama antara perguruan tinggi dengan perguruan tinggi atau lembaga lain yang terkait dan hasil kuliah diakui melalui mekanisme transfer Satuan Kredit Semester.

4. Proses pembelajaran di luar program studi ditentukan oleh Kementrian dan/atau pemimpin perguruan tinggi.

5. Proses pembelajaran di luar program studi dilaksanakan di bawah bimbingan dosen.

6. Proses pembelajaran di luar program studi dilaksanakan hanya bagi program sarjana dan program sarjana terapan di luar bidang kesehatan.

Hak belajar diberikan kepada mahasiswa tiga semester di luar program studi yaitu berupa satu semester kesempatan mengambil mata kuliah di luar program studi dan dua semester melaksanakan kegiatan pembelajaran di luar perguruan tinggi. Bentuk kegiatan di luar perguruan tinggi dapat berupa magang atau praktik kerja di industri atau tempat kerja lainnya, melaksanakan proyek pengabdian kepada masyarakat di desa, mengajar di satuan Pendidikan, mengikuti pertukaran mahasiswa, melakukan penelitian, melakukan kegiatan kewirausahaan, membat studi atau proyek independen, dan mengikuti program kemanusiaan.

Tujuan MBKM adalah untuk meningkatkan komptensi lulusan, baik soft skills maupun hard skills agar lebih siap dan relevan dengan kebutuhan zaman, menyiapkan lulusan sebagai pemimpin masa depan bangsa yang unggul dan berkepribadian. Bentuk kegiatan pembelajaran mengacu pada Permendikbud No. 3 Tahun 2020 Pasal 15 Ayat 1 dinyatakan dapat dilakukan di dalam program studi dan di luar program studi yang meliputi:

\section{Pertukaran Pelajar}

Pertukaran pelajar dilakukan antar perguruan tinggi dengan sistem transfer kredit. Pertukaran pelajar dapat membentuk sikap mahasiswa seperti menghargai keanekaragaman budaya, pandangan, agama, kepercayaan, pendapat atau temuan orisinal orang lain, bekerjasama, memiliki kepekaan sosial atau kepedulian sosial terhadap masyarakat dan lingkungan. Adapun tujuan pertukaran pelajar ini adalah: (1) Belajar lintas kampus (dalam dan luar negeri), sehingga terbangun persaudaraan lintas budaya dan suku. (2) Membangun persahabatan mahasiswa antar daerah, suku, budaya, dan agama sehingga terbangun semangat persatuan dan kesatuan bangsa. (3) Melaksanakan transfer ilmu pengetahuan untuk menutupi disparitas Pendidikan, baik antar perguruan tinggi dalam negeri maupun kondisi tinggi dalam negeri dengan luar negeri.

Dalam program studi lain pada perguruan tinggi yang sama, kegiatan pembelajaran dilaksanakan secara tatap muka atau dalam jaringan (daring). Bentuk pembelajaran yang diambil untuk menunjang tercapainya capaian pembelajaran yang telah tertuang dalam struktur kurikulum atau pengembangan kurikulum dalam memperkaya capaian pembelajaran lulusan dalam bentuk mata kuliah pilihan.

\section{Tabel 1. Capaian Pembelajaran Lulusan dan Kompetensi Tambahan}

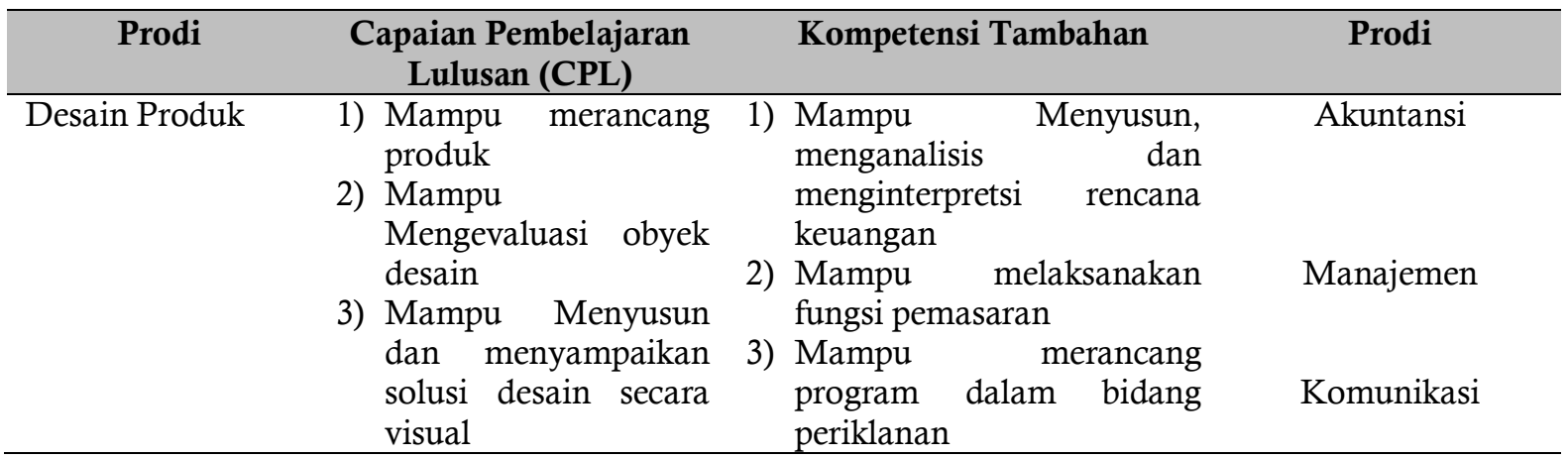

Sumber: Panduan MBKM 2020 Kemendikbud. 
Sebagai salah satu contoh kegiatan pembelajaran dalam program studi lain pada perguruan tinggi yang sama misalnya mahasiswa Prodi Desain Produk harus mampu menguasai minimal kegita CPL prodi, tetapi memerlukan kompetensi tambahan yang dapat diambil dari prodi lain yaitu prodi Akuntansi yang menunjang kompetensi lulusan. Dengan demikian mahasiswa dapat mengambil mata kuliah di Prodi Akuntansi, prodi Manajemen atau Prodi Komunikasi. Untuk lebih jelasnya dapat dilihat pada tabel di bawah ini:

Untuk memperkaya pengalaman dan keilmuan, mahasiswa dapat mengikuti bentuk pembelajaran di perguruan tinggi lain dengan prodi yang sama. Perguruan tinggi yang dipilih adalah yang memiliki kekhasan atau dapat menunjang pembelajaran dan mengoptimalkan CPL. Pembelajaran dapat dilakukan secara tatap muka atau dalam jaringan (daring). Pembelajaran secara daring dengan ketentuan mata kuliah yang ditawarkan harus mendapat pengakuan dari Kemdikbud. Sebagai contoh Prodi kehutanan pada PT A dan PT B memiliki CPL yaitu mampu merancang dan mengelola suatu ekosistem hutan. Mahasiswa PT A dapat mengambil mata kuliah yang ditawarkan oleh PT B atau sebaliknya.

\section{Tabel 2. CPL Prodi dan Mata Kuliah Pergutuan Tinggi}

\begin{tabular}{|c|c|c|c|}
\hline Prodi & CPL Prodi & MK Prodi PT A & MK Prodi PT B \\
\hline Kehutanan & $\begin{array}{l}\text { Mampu merancang dan } \\
\text { mengelola suatu } \\
\text { ekosistem hutan }\end{array}$ & $\begin{array}{l}\text { 1) Pengelolaan } \\
\text { ekosistem hutan } \\
\text { mangrove } \\
\text { 2) Pengelolaan } \\
\text { ekosistem hutan } \\
\text { pegunungan }\end{array}$ & $\begin{array}{l}\text { 1) Pengelolaan } \\
\text { ekosisitem hutan } \\
\text { dataran rendah } \\
\text { 2) Pengelolaan } \\
\text { ekosistem hutan } \\
\text { pantai }\end{array}$ \\
\hline
\end{tabular}

Sumber: Panduan MBKM 2020 Kemendikbud

Selain itu, kegiatan pembelajaran dalam program studi lain pada perguruan tinggi yang berbeda dapat dilakukan secara tatap muka atau dalam jaringan (daring). Mata kuliah yang ditawarkan harus mendapat pengakuan dari Kemdikbud. Contohnya mahasiswa Prodi Teknik Industri pada PT A harus mampu menguasai CPL untuk merancang sistem atau komponen, proses dan produk industri untuk memenuhi kebutuhan dalam batasan-batasan realistis misalnya ekonomi, lingkungan, dan kesehatan. Mereka memerlukan kompetensi tambahan dari prodi lain di PT berbeda. Mahasiswa dapat mengambil mata kuliah Energi dan Mesin Pertanian pada Prodi Teknologi Pertanian PT B, dan mata kuliah Permodelan Ekonomi Sumber Daya dan Lingkungan. Lebih jelasnya lihat tabel di bawah ini:

Tabel 3. CPL Prodi dan Kompetensi Tambahan

\begin{tabular}{|c|c|c|c|}
\hline Prodi & CPL Prodi & Kompetensi Tambahan & MK Prodi Lain PT lain \\
\hline Teknik Industri & $\begin{array}{l}\text { Mampu merancang } \\
\text { sistem/komponen, proses } \\
\text { dan produk industry untuk } \\
\text { memenuhi kebutuhan dalam } \\
\text { Batasan-batasan realistis } \\
\text { misalnya ekonomi, } \\
\text { lingkungan, Kesehatan) }\end{array}$ & $\begin{array}{l}\text { Mampu merancang } \\
\text { produk untuk } \\
\text { kebutuhan pertanian } \\
\text { Mampu membangun } \\
\text { model } r \text { untuk } \\
\text { menganalisis sumber } \\
\text { daya dan lingkungan }\end{array}$ & $\begin{array}{l}\text { Energi dan Mesin } \\
\text { Pertanian } \\
\text { Permodelan Ekonomi } \\
\text { Sumber Daya dan } \\
\text { Lingkungan }\end{array}$ \\
\hline
\end{tabular}

Sumber: Panduan MBKM 2020 Kemendikbud

Jurnal Sikola: Jurnal Kajian Pendidikan dan Pembelajaran Vol. 2, No. 3, Th. 2021 


\section{Magang/Praktik Kerja}

Magang dilakukan 1-2 semester dengan melakukan pembelajaran langsung di tempat kerja (experiential learning). Kegiatan selama 6 bulan disetarakan dengan 20 sks yang dinyatakan dalam bentuk kompetensi dalam bentuk hard skills dan soft skills. Kegiatan pembelajaran dilakukan melalui kerjasama dengan mitra seperti perusahaan, Yayasan nirlaba, organisasi multilateral, institusi pemerintah, dan perusahaan rintisan. Mahasiswa memperoleh hard skills seperti keterampilan, complex problem solving, dan analytical skills. Sedangkan soft skills seperti etika profesi/kerja, komunikasi, kerjasama dan sebagainya. Kegiatan pembelajaran di industri menjadikan mahsiswa mengenal tempat kerja dan lebih siap memasuki dunia kerja nantinya. Bagi perguruan tinggi, juga memperoleh informasi terkait permasalahan yang dihadapi di dunia industri.

Ada dua bentuk penyetaraan bobot kegiatan yaitu bentuk bebas (free form) dan bentuk terstruktur (structured form). Selain bentuk bebas dan terstuktur, ada juga bentuk gabungan (hibrida). Pertama, bentuk bebas (free form) merupakan kegiatan selama 6 bulan disetarakan dengan 20 sks tanpa penyetaraan dengan mata kuliah, namun dinyatakan dalam bentuk capaian kompetensi hard skills dan soft skills. Misalnya mahasiswa magang di industri selama 6 bulan bentuk vapaian kompetensinya adalah:

\section{Hard Skills}
a. Merumuskan permasalahan keteknikan
$: 3$ sks
b. Menyesuaikan permasalahan teknis di lapangan : 3 sks
c. Kemampuan sintesa dalam bentuk design : 4 sks

\section{Soft Skills}
a. Kemampuan berkomunikasi
$: 2 \mathrm{sks}$
b. Kemampuan bekerjasama
$: 2 \mathrm{sks}$
c. Kerja keras
$: 2$ sks
d. Kepemimpinan
$: 2 \mathrm{sks}$
e. Kreativitas
$: 2$ sks

Kedua, bentuk berstruktur (structured form) dilaksanakan secara tersturktur sesuai dengan kurikulum yang ditempuh oleh mahasiswa. 20 sks dinyatakan dalam bentuk penyetaraan dengan mata kuliah dimana kompetensinya sejalan dengan kompetensi kegiatan magang. Contoh mahasiswa Teknik Kimia magang di Industri Petrokimia setara dengan belajar mata kuliah yaitu:
a. Fenomena transport
$: 2 \mathrm{sks}$
b. Unit operasi
$: 3 \mathrm{sks}$
c. Industri proses kimia
$: 3 \mathrm{sks}$
d. Rekayasa reaksi kimia
: 3 sks
e. Kontrol proses kimia
$: 3$ sks
f. Teknologi separasi
: 2 sks
g. Laporan Akhir sebagai pengganti skripsi
: 4 sks

\section{Asistensi Mengajar di Satuan Pendidikan}

Kegiatan pembelajaran dalam bentuk asistensi mengajar dapat dilakukan di sekolah dasar, sekolah menengah pertama dan sekolah menengah atas. Tempat praktik di sekolah bisa sekolah yang berada di daerah kota dan terpencil. Tujuan asistensi mengajar adalah (1) Memberikan kesempatan kepada mahasiswa yang berminat dalam bidang pendidikan untuk memperdalam 
praktek dan keilmuan menjadi guru di sekolah; dan (2) Membantu meningkatkan pemerataan kualitas pendidikan serta relevansi pendidikan dasar dan menengah dengan perguruan tinggi.

\section{Penelitian}

Kegiatan ini memberi kesempatan kepada mahasiswa yang berminat menjadi peneliti. Bentuk kegiatan dapa dilakukan di lembaga riset atau pusat studi. Terlibatnya mahasiswa dalam penelitian dapat membangun cara berpikir kritis sehingga mereka dapat mendalami, memahami, dan mampu melakukan metode riset secara lebih baik. Kegiatan dapat dilakukn selama 1-2 semester.

Ada tiga hal yang menjadi tujuan kegiatan penelitian yaitu (1) Mahasiswa diharapkan dapat ditingkatkan mutunya karena memperoleh pengalaman dalam proyek penelitian sehingga memperkuat peneliti secara topikal; (2) Memperoleh kompetensi penelitian melalui pembimbingan langsung di lembaga riset atau pusat studi; dan (3) Meningkatkan ekosisitem dan kualitas riset di laboratorium sehingga adanya regenerasi peneliti. Mahasiswa didampingi selama melakukan penelitian dan melakukan riset sesuai arahan lembaga riset, membuat logbook dan Menyusun laporan di akhir kegiatan.

\section{Proyek Kemanusiaan}

Indonesia banyak mengalami bencana alam seperti gempa bumi, erupsi gunung berapi, tsunami, bencana hidrologi dan sebagainya. Dengan adanya bencana tersebut mahasiswa dapat menjadi "foot soldiers" dalam proyek-proyek kemanusiaan dan pembangunan. Tujuan program proyek kemanusiaan ini adalah (1) Menyiapkann mahasiswa yang unggul dan menjunjung tinggi nilai kemanusiaan dalam menjalankan tugas berdasarkan agama, moral dan etika; dan (2) Melatih mahasiswa memiliki kepekaan sosial untuk menggali dan menyelami permasalahan yang ada dan ikut memberikan solusi sesuai dengan minat dan keahlian masing-masing. Mahasiswa didampingi oleh dosen dan lembaga mitra untuk mengawasi, menilai dan mengevaluasi kegiatan yang dilakukan. Lembaga mitra bisa berada di dalam negeri maupun luar negeri. Lembaga mitra dalam negeri seperti Pemda, PMI, BPBD, BNPB dan sebagainya. Sedang Lembaga mitra luar negeri seperti UNESCO, WHO, UNHCR, UNOCHA dan sebagainya.

\section{Kegiatan Wirausaha}

Kegiatan wirausaha mendorong pengembangan minat mahasiswa di bidang wirausaha. Tujuannya adalah (1) Mahasiswa yang memiliki minat berwirausaha agar mengembangkan usahanya lebih dini dan secara terbimbing; dan (2) Menangani permasalahan pengangguran seperti pengangguran intelektual di kalangan sarjana. Kegiatan pembelajaran dilakukan dalam bentuk wirausaha yang belum atau sudah ditetapkan dalam kurikulum program studi. Selama melakukan kegiatan, mahasiswa dibimbing oleh dosen. Kegiatan dilakukan dapat memenuhi 20 sks/semester atau 40 sks/tahun. Ukuran keberhasilan capaian pembelajaran bila mahasiswa berhasil membuat start up di akhir, maka mendapatkan nilai A.

\section{Studi/Proyek Independen}

Proyek independen untuk melengkapi topik yang tidak termasuk dalam jadwal perkuliahan namun terdapat dalam silabus program studi atau fakuktas. Mahasiswa bisa membuat karya inovatif untuk dilombakan di tingkat nasional dan internasional. Kegiatan ini dapat dijadikan sebagai pengganti mata kuliah yang harus diambil dan dihitung berdasarkan kontribusi dan peran mahasiswa yang berkoordinasi dengan dosen pembimbing.

Adapun tujuan studi/proyek independen ini adalah: (1) Mewujudkan gagasan mahasiswa dalam mengembangkan produk inovatif; (2) Menyelenggarakan Pendidikan berbasis riset dan 
pengembangan (R\&D); dan (3) Meningkatkan prestasi mahasiswa dalam ajang nasional dan internasional.

\section{Membangun Desa/Kuliah Kerja Nyata Tematik (KKNT)}

KKNT adalah bentuk pendidikan dengan cara memberikan pengalaman belajar kepada mahasiswa untuk hidup di tengah masyarakat, mengidentifikasi potensi, dan menangani masalah, mengembangkan potensi desa/daerah dan merumuskan solusi terhadap masalah yang dihadapi masyarakat. Setelah melakukan kegiatan, mahasiswa membuat laporan akhir.Tujuan program KKNT ini adalah (1) Kehadiran mahasiswa selama 6-12 bulan dapat memberikan kesempatan untuk memanfaatkan ilmu pengetahuan, teknologi, dan keterampilan yang dimiliki dan bekerjasama dengan pemangku kepentingan di lapangan; (2) Membantu percepatan pembangunan di wilayah pedesaan bersama dengan Kementrian Desa PDT.

\section{Aliran Humanisme tentang Pendidikan}

Humanistik adalah aliran dalam psikologi yang muncul tahun 1950-an sebagai reaksi terhadap aliran yang telah ada sebelumnya yaitu behaviorisme dan psikoanalisis. Aliran ini secara eksplisit memberi perhatian pada dimensi manusia dari psikologi dan konteks manusia dalam pengembangan teori psikologis.

Humanisme berasal dari kata latin yaitu humanus dari kata homo yang berarti manusia dan diartikan sebagai sifat manusia. Humanisme secara filsafat adalah suatu aliran yang memandang manusia agar bermartabat luhur, mampu menentukan nasib sendiri, dan dengan kekuatan sendiri mampu mengembangkan diri dalam kemampuan berpikir untuk dirinya sendiri dan dunia.

Aliran ini ditelusuri pada masa klasik barat dan masa klasik timur. Dasar pemikiran filsafat pendidikan ditemukan dalan filsafat klasik Cina Konfusius dan pemikiran filsafat klasik Yunani. Pada masa reneisance, perkembangan filsafat, ilmu dan kemanusiaan mengalami kebangkitan setelah lama dikungkung oleh kekerasan dogma-dogma agama. Pada abad ke 18, pada masa pencerahan dipimpin oleh Rosseeu, dan pada abad ke 20 perkembangan humanisme merupakan gerakan protes terhadap dominasi kekuatan-kekuatan yang megancam eksisitensi nilai-nilai kemanusiaan yang ada pada dii manusia di era modern.

Beberapa ahli psikologi tidak mengakui psikologi humanistik sebagai teori psikologi, tetapi dikatakan sebagai suatu gerakan. Sebaliknya ahli juga memandang bahwa humanistik sebagai $a$ third force learning theory (Ornstein \& Hunkins, 2013) setelah behaviorisme dan kognitivisme. Teori humanistik termasuk constructivist, karena teori ini melibatkan proses kognitif dan afektif dalam tingkah laku. Artinya, teori memadukan, kapabilitas dan potensi sehingga manusia bisa mandiri memilih dan mengatur hidupnya.

Teori belajar humanistik pada dasarnya memiliki tujuan belajar untuk memanusiakan manusia. Oleh karena itu proses belajar dapat dianggap berhasil apabila si pembelajar telah memahami lingkungannya dan dirinya sendiri. Dengan kata lain, si pembelajar dalam proses belajar harus berusaha agar lambat laun mampu mencapai aktualisasi diri dengan sebaik-baiknya.

Menurut Sukardjo \& Ukim (2015) dijelaskan bahwa pendekatan humanistik dalam pendidikan memfokuskan pada pencarian manusia dalam menemukan potensi dirinya mencakup kemampuan interpersonal, sosial dan metode untuk mengembangkan diri. Tujuan pengembangan kemampuan adalah untuk memperkaya diri, menikmati keberadaan hidup dan masyarakat (Sukardjo \& Ukim, 2015).

Sementara itu, Lefrancois (1988) mengatakan bahwa pendekatan humanistik mengkaji tentang keunikan, individualitas, dan kemanusiaan tiap individu. Kapabilitas dan potensi dipadukan sehingga manusia dapat mandiri untuk memilih dan mengatur hidupnya sendiri (Lefrancois, 1988). Berikutnya, Weiner (1992) dalam Shunk (2012) mengemukakan dua asumsi terkait dengan kajian humanistik ini yaitu: (1) untuk memahami orang secara holistik, maka perlu mengkaji tingkah laku, pikiran, dan perasaan mereka, dan (2) pilihan manusia, kreativitas, dan 
aktualisasi diri perlu diteliti karena dapat mencakup fungsi organisme psikologis dan kreativitas manusia melalui optimalisasi kapabilitas dan potensinya. Implikasi dari asumsi tersebut, salah satunya diungkap oleh Ornstein \& Hunkins (2013) bahwa motivasi adalah aspek penting tingkah laku yang melibatkan potensi manusia untuk memenuhi kebutuhan hidupnya (Ornstein \& Hunkins, 2013).

Berdasarkan paparan di atas, dapat diidentifikasi hal-hal penting dalam pendekatan pendidikan humanistik ini yaitu:

\section{Belajar Bagaimana Belajar}

Dalam teori belajar humanistik mengorientasikan hasil belajar afektif dikembangkan melalui keterampilan belajar peserta didik sehingga dia dapat melakukan learning how to learn, meningkatkan kreativitas dan potensi kemampuan masing-masing peserta didik. Slavin menyatakan psikologi belajar ini mendorong peserta didik menjadi pembelajar mandiri (selfdirected learners atau self-motivated learners) dari pada menjadi penerima pasif informasi dari guru (Slavin, 2008). Selanjutnya Schunk (2012) mengatakan bahwa motivasi penting untuk memaksimalkan potensi diri masing-masing peserta didik. Ini menunjukkan bahwa pengembangan afektif sejajar dengan kognitif dan psikomotorik dalam pembelajaran (Schunk, 2012). Oleh sebab itu, aliran humanistik terkait dengan cara pandang tentang diri kita sendiri (self concept) yang kemudian menentukan tingkah laku peserta didik, termasuk dalam tingkah laku belajar. Sebagaimana diungkapkan oleh Combs, et al (1974) "the selfhas to be achieved; it is not given" (diri kita adalah hasil ciptaan kita sendiri bukan bentukan orang lain) (Combs, 1974).

\section{Pembelajaran Mandiri}

Aliran humanisme memandang manusia adalah unik. Keunikan manusia tersebut menunjukan kedirian (self) mereka masing-masing. Untuk itu fokusnya adalah pada diri individu dalam upaya mengkaji manusia untuk memanusiakan manusia. Implikasi dari pandangan ini mengarahkan bahwa peserta didik harus aktif mengarahkan dirinya sendiri dalam memilih apa yang akan dipelajarinya, seberapa jauh perlu didalami dan bagaimana mempelajarinya. Jadi, yang ditekankan adalah bagaimana mewujudkan kemandirian seseorang dalam belajar.

Untuk mewujudkan keaktifan peserta didik dalam mengarahkan dirinya, maka kurikulum harus berfungsi membantu peserta didik memiliki pengalaman instrinsik yang bermanfaat pada kebebasan dan pengembangan individu peserta didik (McNeil, 1977).

Tujuan pendidikan dalam pandangan teori humanistik yaitu proses dinamika pengembangan personel agar peserta didik mencapai perkembangan individu, integritas diri dan otonomi menuju aktualisasi diri (self actualization). Kurikulum humanistik tidak hanya menekankan pengembangan aspek kognitif, namun juga mengembangkan aspek afektif.

\section{Pendidikan Afektif}

Ornstein \& Hunkins (2013) mengemukakan untuk menjadi manusia seutuhnya, manusia Pendidikan humanustik lebih ditekankan pada ranah afektif bukan kognitif. Untuk itu, kurikulum harus berorientasi nilai-nilai seperti empati, toleransi, peduli, kerja sama, saling menghargai, kejujuran, berakhlak mulia, dan sebagainya. Aplikasinya tidak hanya terlaksana dalam pembelajaran di kelas (teori), namun juga terefleksi atau praktiknya pada budaya potensi sekolah sebagai pemberi teladan (Ornstein \& Hunkins, 2013).

\section{Motivasi Diri}

Pendidikan dalam teori belajar humanistik mementingkan perlunya mengajar peserta didik agar belajar dalam keadaan menyenangkan, menilai tinggi dan bersikap postif terhadap belajar untuk dirinya. Belajar yang demikian menurut Slavin (Slavin, 2008) dapat dicapai dengan pembelajaran yang memotivasi peserta didik melakukan berbagai kegiatan belajar yang 
mengharuskan akses informasi, menetapkan keputusan, memecahkan masalah, dan menghasilkan suatu produk.

Dalam pembelajaran pendidik berperan sebagai fasilitator bukan penyaji materi pelajaran. Sekolah harus berfungsi sebagai tempat yang nyaman agar dapat memotivasi peserta didik dalam mengembangkan potensi dirinya sehingga dapat membelajarkan mereka menjadi manusia seutuhnya (a whole person) (Ansyar, 2015).

Arthur W. Combs berpendapat bahwa banyak pendidik membuat kesalahan dengan berasumsi bahwa peserta didik mau belajar apabila materi pelajarannya disusun dan disajikan sebagaimana mestinya. Peserta didik mengharapkan makna dari materi, tetapi tidak menyatu dalam materi tersebut. Yang terpenting adalah bagaimana membawa persepsi peserta didik untuk memperoleh makna belajar bagi dirinya dari materi pelajaran tersebut yang menghubungkan materi dengan kehidupan sehari-hari (Sukardjo \& Ukim, 2015).

Combs memberikan lukisan persepsi diri dan dunia seseorang seperti dua lingkaran (besar dan kecil) yang bertitik pusat satu. Lingkaran kecil adalah gambaran dari persepsi diri dan lingkaran besar adalah persepsi dunia. Makin jauh peristiwa-peristiwa dari persepsi diri, makin berkurang pengaruhnya terhadap perilaku. Jadi, hal-hal yang sedikit hubungannya dengan diri peserta didik, maka makin mudah terlupakan oleh peserta didik.

Teori Maslow didasarkan pada asumsi yaitu 1) suatu usaha yang positif untuk berkembang; dan 2) kekuatan untuk melawan atau menolak perkembangan itu. Menurut Maslow, individu berperilaku dalam upaya untuk memenuhi kebutuhan yang bersifat hirarkis. Pada diri setiap orang terdapat berbagai rasa takut seperti rasa takut untuk berusaha atau berkembang, takut untuk mengambil keputusan, takut dengan apa yang sudah ia miliki dan sebagainya. Disisi lain, individu juga memiliki dorongan untuk lebih maju ke arah keutuhan, keunikan diri, ke arah berfungsinya semua kemampuan, ke arah kepercayaan diri menghadapi dunia luar dan pada saat itu juga ia dapat menerima diri sendiri.

Maslow membagi kebutuhan-kebutuhan (needs) manusia menjadi tujuh hirarki yaitu bila seseorang telah dapat memenuhi kebutuhan pertama seperti kebutuhan fisiologis, barulah ia menginginkan kebutuhan di atasnya yaitu kebutuhan mendapatkan rasa aman dan seterusnya. Hirarki kebutuhan ini mempunyai implikasi penting yang harus diperhatikan pendidik pada waktu mengajar. Motivasi belajar mungkin berkembang kalau kebutuhan dasar peserta didik belum terpenuhi.

Carl Rogers membedakan dua tipe belajar, yaitu kognitif (kebermaknaan) dan experiential (pengalaman atau signifikan). Pendidik menghubungkan pengetahuan akademik ke dalam pengetahuan terpakai seperti mempelajari mesin dengan tujuan untuk memperbaiki.

Experiential Learning menunjuk pada pemenuhan kebutuhan dan keinginan peserta didik. Kualitas belajarnya adalah mencakup keterlibatan siswa secara personal, berinisiatif, evaluasi oleh peserta didik sendiri, dan adanya efek yang membekas pada peserta didik. Menurut Rogers, yang terpenting dalam proses pembelajaran adalah pentingnya pendidik memperhatikan prinsip pendidikan dan pembelajaran yaitu:

1) Menjadi manusia berarti memiliki kekuatan yang wajar untuk belajar (tidak harus belajar tentang hal-hal yang tidak ada artinya).

2) Siswa akan mempelajari hal-hal yang bermakna bagi dirinya (mengorganisasikan ide dan bahan pelajaran yang bermakna bagi dirinya).

3) Pengorganisasian bahan pelajaran berarti mengorganisasikan bahan dan ide baru sebagai bagian hal yang bermakna.

4) Belajar yang bermakna dalam masyarakat modern berati belajar tentang proses.

Aplikasi aliran humanisme dalam belajar, lebih menunjukkan pada roh atau spirit selama proses pembelajaran yang mewarnai metode-metode yang diterapkan. Peran pendidik dalam pembelajaran humanistik adalah menjadi fasilitator bagi para peserta didik dengan memberikan motivasi terkait dengan kesadaran tentang makna belajar dalam kehidupan peserta didik. Pendidik 
memberikan fasilitas pengalaman belajar peserta didik dan mendampingi mereka untuk memperoleh tujuan pembelajaran.

Makna adalah konsep dasar yang sering digunakan dalam teori belajar humanistik. Dengan demikian, belajar terjadi bila mempunyai arti bagi individu. Pendidik tidak dapat memaksakan materi yang tidak disukai atau tidak relevan dengan kehidupan mereka. Untuk itu pendidik harus memahami perilaku peserta didik dengan mencoba memahami dunia persepsi mereka sehingga apabila ingin mengubah perilaku mereka. Pendidik harus berusaha mengubah keyakinan atau pandangan peserta didik.

Peserta didik berperan sebagai pelaku utama (student centered) yang memaknai proses pengalaman belajarnya sendiri. Dengan peran tersebut diharapkan siswa memahami potensi diri, mengembangkan potensi dirinya secara positif dan meminimalkan potensi diri negatif.

Sukardjo (2015) menjelaskan tujuan belajar pendidikan humanistik lebih ditekankan pada proses belajar daripada hasil belajar. Proses yang dilalui umumnya adalah:

1. Merumuskan tujuan belajar yang jelas.

2. Mengusahakan partisipasi aktif peserta didik.

3. Mendorong peserta didik untuk mengembangkan kemampuan untuk belajar atas inisiatif sendiri.

4. Mendorong peserta didik untuk peka berpikir kritis, memaknai proses pembelajaran secara mandiri.

5. Mendorong peserta didik untuk mengemukakan pendapat, memilih pilihannya sendiri, melakukan apa yang diinginkan dan menanggung resiko. Pendidik menerima anak didik apa adanya dan berusaha memahami jalan pikiran mereka, mendorong bertanggung jawab dan resiko perbuatannya.

6. Memberikan kesempatan kepada peserta didik untuk maju sesuai dengan kecepatannya. Evaluasi diberikan secara individual berdasarkan perolehan prestasi peserta didik.

Pembelajaran berdasarkan teori humanistik cocok diterapkan pada materi-materi pembelajaran yang bersifat pembentukan kepribadian, hati nurani, perubahan sikap, dan analisis terhadap fenomena sosial. Misalnya dalam mata pelajaran sosiologi materi sosialisasi dan kepribadian, perilaku menyimpang, masalah sosial, nilai dan norma, pengendalian sosial dan sebagainya.

Indikator keberhasilan belajar adalah peserta didik senang, bergairah, inisiatif dalam belajar dan terjadi perubahan pola pikir, perilaku, sikap atas kemauan sendiri. Peserta didik diharapkan menjadi manusia yang bebas, berani, tidak terikat oleh pendapat orang lain dan mengatur pribadinya sendiri secara bertanggung jawab tanpa mengurangi hak-hak orang lain atau melanggar aturan, norma, disiplin, atau etika yang berlaku.

\section{Merdeka Belajar dan Kampus Merdeka Dalam Pandangan Humanisme}

Menurut H.A.R Tilaar (2005) pendidikan merupakan proses memanusiakan anak manusia yaitu menyadari akan manusia yang merdeka. Manusia merdeka adalah manusia yang kreatif yang terwujud dalam budayanya (Tilaar, 2005). Di Indonesia, pendidikan yang bersifat humanis menghargai nilai-nilai keagamaan dan kebudayaan sebagai sumber yang membangun kehidupan menjadi harmonis di antara bermacam etnis, kelompok sosial, agama dan daerah Nilai keagamaan dan kebudayaan harus menjadi nilai inti bagi masyarakat dalam mewujudkan kehidupan yang bersatu, bertoleransi, berkeadilan dan sejahtera.

Konsep pendidikan humanistik menuntut adanya kebebasan agar harkat dan martabat peserta didik terjamin. Kebebasan tidak akan terjadi bila seorang peserta didik tidak terisolasi oleh hal-hal di luar dirinya. Konsep "Merdeka Belajar" yang berarti kemerdekaan berpikir merupakan perwujudan agar peserta didik tidak terisolasi oleh hal-hal di luar dirinya. Sebab, kemerdekaan berpikir membuka sudut pandang seluas-luasnya dalam menyikapi suatu masalah dalam 
kehidupan. Wattimena (2012) menjelaskan bahwa kemerdekaan berpikir merupakan suatu kemampuan untuk mempertimbangkan segala sesuatu secara jernih dan mandiri (Wattimena, 2012). Merdeka dalam berpikir menjadi solusi yang relevan dalam menghadapi berbagai problematika kualitas sumber daya manusia. Untuk itu dengan adanya proses berpikir yang tepat menjadi kunci utama dalam melahirkan sumber daya manusia yang unggul, adaptif dan kompeten (Lubaba, 2020).

Untuk memperoleh kemerdekaan berpikir, ada empat tahap yang harus dilalui oleh seseorang (Wattimena, 2012). Keempat tahap yang harus dilalui dalam kemerdekaan berpikir adalah (1) Peduli atau aware dengan cara berpikir kita sendiri yaitu dengan mengetahui dan memahami apakah cara berpikir kita sudah logis, kritis atau masih asumtif, dipenuhi hal negatif dan sebagainya; (2) Mengakui cara berpikir kita; (3) Membuka diri dan pikiran terhadap berbagai kemungkinan atau dengan kata lain perlu terbuka dengan sudut pandang baru; dan (4) Menjadikan seseorang memiliki perspektif luas sehingga menjadi orang yang bijak dalam mengambil sikap.

"Kampus Merdeka berarti upaya melepaskan belenggu untuk bisa bergerak lebih mudah dan memiliki otonomi mengatur diri sendiri. MBKM memadukan kapabilitas dan potensi mahasiswa dan perguruan tinggi untuk mandiri memilih dan mengatur kegiatan pembelajaran MBKM. Kebijakan kampus merdeka menginginkan perguruan tinggi di Indonesia diberi ruang yang cukup untuk beradaptasi mengikuti perkembangan zaman. Prinsip terpenting yang dikandung dalam kampus merdeka adalah kemerdekaan akademik (academic freedom). Konsep ini umumnya digunakan dalam dunia pendidikan di perguruan tinggi. Namun, sebetulnya kemerdekaan akademik pertama kali dirumuskan oleh filsuf Jerman bernama Wilhelm von Hamboldt (1809). Arti kemerdekaan akademik adalah memberi kebebasan kepada mahasiswa untuk memilih apa yang akan dipelajari, dan bagaimana mereka mempelajari, sedang dosen memiliki kebebasan untuk mengajar ilmu sesuai dengan kepakarannya (Suteja, 2007).

Teori humanistik melibatkan proses kognitif dan afektif dalam tingkah laku. Dalam belajar, teori ini memadukan kapabilitas dan potensi manusia sehingga ia bisa mandiri memilih dan mengatur hidupnya. Proses belajar dapat dianggap berhasil apabila si pembelajar telah memahami lingkungannya dan dirinya sendiri. Si pembelajar dalam proses belajar harus berusaha agar lambat laun mampu mencapai aktualisasi diri dengan sebaik-baiknya (Sukardjo \& Ukim, 2015).

Hak belajar yang diberikan kepada mahasiswa sebanyak tiga semester di luar program studi yaitu satu semester kesempatan mengambil mata kuliah di luar program studi dan dua semester melaksanakan kegiatan pembelajaran di luar perguruan tinggi. Hak belajar ini sejalan dengan belajar dalam teori belajar humanistik peserta didik dijadikan sebagai subjek pembelajaran untuk mengembangkan potensi-potensi peserta didik agar mereka dapat menjadi orang yang diinginkan (what man can become). Implikasinya dapat dilihat pada kurikulum MBKM yang memberikan pengalaman belajar dalam kegiatan di luar perguruan tinggi seperti pertukaran mahasiswa, magang/praktik kerja, asistensi mengajar di satuan pendidikan, penelitian, proyek kemanusiaan, kegiatan wirausaha, studi/proyek independen, dan membangun desa/Kuliah Kerja Nyata Tematik.

Ketika mahasiswa terlibat dalam berbagai kegiatan itu dapat berkontribusi pada pengembangan potensi setiap mahasiswa secara optimal. Dosen hanya sebagai pembimbing, pendamping atau fasilitator dalam proses kegiatan yang dilakukan. Dosen membantu mahasiswa untuk mengenal diri dan mewujudkan potensi-potensi yang ada dalam dirinya. Ini berarti, mahasiswa dapat mengaktualisasikan diri dan mengembangkan semua potensi diri dengan sebaikbaiknya. Filsafat humanisme memandang belajar akan dianggap berhasil bila mahasiswa telah memahami lingkungan dan dirinya sendiri.

Dapat dikatakan bahwa bentuk kegiatan pembelajaran dalam MBKM berorientasi hasil belajar afektif yang dikembangkan melalui keterampilan belajar dimana mahasiswa dapat 
melakukan learning how to learn, meningkatkan kreativitas dan potensi kemanusiaan masingmasing mahasiswa. Kegiatan pembelajaran MBKM juga mendorong mahasiswa agar menjadi pembelajar mandiri (self- directed learners atau self-motivated learners) daripada sebagai penerima pasif pengajaran materi atau informasi. Motivasi sangat berperan tentunya bagi pemenuhan kebutuhan pokok orang, tetapi pilihan lebih besar adalah ketika mahasiswa memaksimalkan potensi diri masing-masing. Dalam ungkapan awam sering kita ketahui learning how to learn berarti "siswa jangan diberi ikan, tetapi ia di beri pancing sehingga ia dapat memancing ikan yang lebih besar dari gurunya". Jadi, pembelajaran dalam MBKM sejalan dengan belajar dalam teori humanistik yang berfokus pada pengembangan aspek afektif belajar dengan kognitif dan psikomotorik dalam tiap proses pembelajaran. Mahasiswa diberi kesempatan belajar yang menghasilkan pengalaman belajar sehingga berkontribusi pada optimalisasi pengembangan potensi dan kemampuannya.

Dari aspek kurikulum, aliran humanisme menganggap pentingnya mengembangkan kepedulian sosial, kreativitas dan suasana belajar yang gembira dan kerehatan berpikir dan jiwa anak didik. Sehingga memunculkan manusia unggul yang memiliki kemampuan intuisi, imajinasi dan moral manusia (Bagir, 2019). MBKM telah memberi ruang atau kesempatan bagi perguruan tinggi dalam mengembangkan karakter-karakter belajar seperti kepedulian sosial, kreativitas, saling menghargai di antara budaya yang berbeda, mandiri, berpikir kritis dan sebagainya. Tentu saja dalam penerapannya, harus disikapi oleh pendidik secara bijaksana dan menjadikan mahasiswanya memiliki karakter-karakter tersebut sehingga menjadi mahasiswa yang unggul, memiliki kepribadian baik, bahagia dan pintar. Konsep "merdeka belajar"yang bermakna kemerdekaan berpikir dan "kampus merdeka" yang bermakna upaya melepaskan belenggu sehingga bisa bergerak lebih mudah dapat terwujud. Jika tidak, maka menjadi bertentangan apabila dalam pengembangannya mahasiswa merasa terbebani dan tertekan dalam MBKM.

Metode belajar MBKM yang memfokuskan pada experience learning membekali anak didik untuk terjun ke masyarakat sehingga dapat dilakukan pembelajaran autentik, pembelajaran kontekstual dan pembelajaran berbasis proyek. Ketiga metode ini sangat cocok dengan model pembelajaran saat ini yang berfokus pada kompetensi. Ketiga metode pembelajaran tersebut juga merupakan aplikasi dari teori belajar humanistik, dimana dosen lebih banyak berperan sebagai fasilitator dan mahasiswa sebagai pelaku utama (student centered) yang memaknai proses pengalamannya sendiri. Sehingga belajar menjadi bermakna bagi diri siswa.

Bagi Rogers, experiential learning memberikan kualitas belajar dan kebermaknaan dalam belajar. Kualitas belajar dan kebermaknaan belajar mahasiswa dalam MBKM dapat terpenuhi karena mereka terlibat secara personal dan berinisiatif dalam kegiatan pembelajaran yang telah diprogramkan sendiri pilihan bentuknya oleh mahasiswa. Mahasiswa berharap memperoleh makna dari materi yang dipelajari dan menghubungkannya dengan kehidupan sehari-hari. Combs memberikan lukisan persepsi diri dan dunia seseorang seperti dua lingkaran (besar dan kecil) yang bertitik pusat satu. Lingkaran kecil adalah gambaran dari persepsi diri dan lingkaran besar adalah persepsi dunia. Makin jauh peristiwa-peristiwa dari persepsi diri, makin berkurang pengaruhnya terhadap perilaku. Jadi, hal-hal yang sedikit hubungannya dengan diri siswa, maka makin mudah terlupakan oleh siswa.

Untuk tercapainya kualitas belajar dan kebermaknaan itu, yang terpenting dalam proses pembelajaran adalah dosen atau perguruan tinggi, memperhatikan prinsip-prinsip belajar humanistik yaitu: Pertama, hasil belajar afektif yang dikembangkan melalui keterampilan belajar sehingga dapat melakukan belajar bagaimana belajar (learning how to learn). Kedua, menjadi pembelajar yang mandiri (self-directed learners atau self- motivated learners) yang mengarahkan mahasiswa harus aktif mengarahkan dirinya sendiri memilih apa yang akan dipelajarinya, seberapa jauh perlu didalami dan bagaimana mempelajarinya. Ketiga, pendidikan afektif untuk menjadi manusia seutuhnya dengan menanamkan nilai-nilai seperti empati, toleransi, peduli, kerja sama, saling menghargai, kejujuran, berakhlak mulia, dan sebagainya. Keempat, 
mementingkan perlunya dosen mengajar dalam keadaan menyenangkan dan bersikap positif terhadap belajar dan berperan sebagai fasilitator. Selanjutnya, kampus dan tempat-tempat belajar mahasiswa harus berfungsi sebagai tempat yang nyaman agar dapat memotivasi mereka dalam mengembangkan potensi dirinya sehingga dapat membelajarkan mereka menjadi manusia seutuhnya (a whole person). Sebagaimana dikemukakan oleh Maslow bahwa individu memiliki dorongan untuk lebih maju ke arah keutuhan, keunikan diri, ke arah berfungsinya semua kemampuan, ke arah kepercayaan diri menghadapi dunia luar dan pada saat itu juga ia dapat menerima diri sendiri. Dosen harus memperhatikan hirarki kebutuhan mahasiswa dalam belajar karena motivasi belajar mungkin berkembang kalau kebutuhan dasar mahasiswa belum terpenuhi.

Terkait dengan tujuan pendidikan, MBKM bertujuan meningkatkan komptensi lulusan, baik soft skills maupun hard skills menyiapkan mahasiswa lebih siap dan relevan dengan kebutuhan perkembangan zaman, menyiapkan lulusan sebagai pemimpin masa depan bangsa yang unggul dan berkepribadian. Hal ini sejalan dengan tujuan pendidikan dalam pendidikan humanistik yaitu proses dinamika pengembangan kemampuan personel agar seseorang mencapai perkembangan individu, integritas diri dan otonomi menuju aktualisasi diri (self actualization). Pengembangan kemampuan adalah untuk memperkaya diri, dan menikmati keberadaan hidup dalam masyarakat yang mengalami perkembangan. Tujuan pendidikan MBKM menekankan proses belajar dari pada hasil seperti halnya dalam pendidikan humanistik yang juga menekankan pada proses belajar bukan pada hasil belajar.

Kemitraan yang dilakukan oleh perguruan tinggi dengan dunia usaha (industri) dan negara dapat menjadi lompatan inovasi yang memberi manfaat terhadap ketiga komponen tersebut. Kerjasama perguruan tinggi dengan dunia kerja berdampak positif bagi semua pemangku kepentingan yang terlibat seperti mahasiswa, dosen, tenaga kependidikan, pengusaha, masyarakat, negara dan sebagainya. Pengembangan inovasi harus difokuskan kepada pembelajaran mahasiswa, isi mata kuliah, metode belajar, keterampilan dan kompetensi yang diperlukan. Agar pengembangan inovasi dalam pembelajaran tersebut dapat terlaksana, maka kemitraan atau kerjasama mencakup mahasiswa, dosen dan pimpinan perguruan tinggi sebagai tiga aktor dalam membangun sinergisitas kebutuhan masa depan sesuai dengan perkembangan zaman.

Selanjutnya, kerjasama antara perguruan tinggi dan dunia usaha sebaikya berdasarkan desain dalam kerangka meningkatkan profesionalitas civitas akademika. Desain ini akan mempengaruhi perumusan kurikulum dalam penentuan capaian pembelajaran (learning outcomes) dan penempatan kuliah di luar perguruan tinggi (Munadi, 2020).

Aliran Filsafat Humanisme melihat masing-masing individu peserta didik seperti mahasiswa memiliki keunikan/karakteristik, potensi dan motivasi yang berbeda-beda. Konsep ini mengarahkan pada pentingnya membelajarkan mahasiswa sesuai dengan karakteristiknya sehingga mereka sampai pada tingkat mampu mengaktualisasikan dirinya. Keseragaman kurikulum dan ruang lingkup praktek yang sama dapat mempersempit gerak mahasiswa untuk berekspresi dan memperoleh kompetensi utama dan kompetensi pendamping yang diharapkan. Sehingga diperlukan pengembangan kurikulum yang memberikan keleluasaan kepada mahasiswa untuk memilih aspek pengembangannya sesuai dengan kerja sama mitra yang telah dirancang oleh program asal mahasiswa. Program ini diharapkan memberikan pengalaman barukepada mahasiswa untuk memilih program sesuai dengan karakteristik dan minatnya, mendorong motivasi mahasiswa, menjadikannya alumni yang berdaya guna bagi kehidupan dan masyarakat di sekitarnya. Suatu pembelajaran akan berhasil jika dapat menciptakan perubahan pada diri peserta didik, baik kognitif, afektif maupun psikomotorik dengan mempertimbangkan kondisi peserta didik yang memiliki potensi dan karakteristik yang berbeda-beda.

\section{Kesimpulan}

Merdeka Belajar dan Kampus Merdeka dapat dikaji dalam perspektif aliran humanisme. Humanisme sebagai salah satu aliran dalam filsafat pendidikan menekankan pada proses kognitif 
dan afektif dalam belajar, teori ini memadukan kapabilitas dan potensi manusia sehingga ia bisa mandiri memilih dan mengatur hidupnya. Si pembelajar dalam proses belajar harus berusaha agar lambat laun mampu mencapai aktualisasi diri dengan sebaik-baiknya. Metode belajar MBKM yang memfokuskan pada experience learning dapat membekali mahasiswa untuk terjun ke masyarakat dan memberikan kualitas belajar dan kebermaknaan dalam belajar. Kualitas belajar dan kebermaknaan belajar mahasiswa dalam MBKM dapat terpenuhi karena mereka terlibat secara personal dan berinisiatif dalam kegiatan pembelajaran yang telah diprogramkan sendiri pilihan bentuknya oleh mahasiswa. Kualitas belajar dan kebermaknaan belajar dapat dicapai dengan menerapkan prinsip belajar humanistik yaitu belajar bagaimana belajar (learning how to learn), pembelajaran mandiri, memotivasi diri, dan pendidikan afektif. Dengan demikian, tujuan pendidikan MBKM yang diharapkan untuk mengembangkan hard skills dan soft skills, menyiapkan mahasiswa lebih siap dan relevan dengan kebutuhan perkembangan zaman, menyiapkan lulusan sebagai pemimpin masa depan bangsa yang unggul dan berkepribadian dapat dicapai secara optimal.

\section{Daftar Pustaka}

Bagir, H. (2019). Memulihkan Sekolah Memulihkan Manusia Meluruskan Kembali Falsafah Pendidikan Kita. Bandung: PT. Mizan Pustaka.

Combs, C. (1974). The Profesional Education of Teachers; A Humanistic Approach to Teacher Preparation. Boston: Asllyn and Bacon, Inc.

Danim, S. (2002). Menjadi Peneliti Kualitatif. Bandung: Pustaka Setia.

Lefrancois, G. R. (1988). Psychology for Teaching. Belmont California: Wadsworth Publishing Company.

Lubaba, H. (2020). Merdeka dalam Berpikir. Jakarta: Bumi Aksara.

McNeil, J. D. (1977). Curriculum: A Compehensive Introduction. Boston: Litle Brown and Company.

Munadi, H. (2020). Merdeka Belajar, Kampus Merdeka: Bagaimana Mendesain Ulang Kurikulum. Journal of Quality in Higher Education, 2(3), 1-10.

Mustaghfiroh, S. (2020). Konsep "Merdeka Belajar"Perspektif Aliran Progresivisme John Dewey. Jurnal Edureligia. Jurnal Pendidikan Agama Islam, 4(1), 141-147.

Nazir, M. (1988). Metode Penelitian. Jakarta: Ghalia Indonesia.

Ornstein, A. C., \& Hunkins, F. P. (2013). Curriculum: Foundations, Principles, and Issues. Boston: Pearson.

Pohan, J. E. (2019). Filsafat Pendidikan Teori Klasik Hingga Postmodernisme dan Problematikanya di Indonesia. Depok: Rajawali Press.

Schunk, D. H. (2012). Learning Theories: An Educational Perspectives. Boston: Pearson Education, Inc.

Slavin, R. E. (2008). Psikologi Pendidikan Teori dan Praktik. Jakarta: Indek.

Sukardjo, S., \& Ukim, K. (2015). Landasan Pendidikan Konsep dan Aplikasinya. Jakarta: Rajawali Press.

Suteja, J. (2007). Kampus Merdeka: Merdeka Belajar. Bandung: Unpas Press.

Tilaar, H. A. R. (2005). Manifesto Pendidikan Nasional, Tinjauan dari Perspektif Postmodernisme dan Studi Kultural. Jakarta: Penerbit Buku Kompas.

Wattimena, R. A. (2012). Kemerdekaan Pikiran. Depok: Rajawali Press.

Zais, R. S. (1976). Curriculum: Principles, and Faoundations. New York: Harper \& Row Publisher. 